\title{
Mouthwashes Help in Reducing Spread of COVID-19 Infection
}

\author{
Mahantayya Veerabhadrayya Math ${ }^{1, *}$, Yashoda Ravindra Kattimani ${ }^{2}$, Rohit Bhailal Gadda ${ }^{3}$
}

\section{Mahantayya Veerabhadrayya Math ${ }^{1, *}$, Yashoda Ravindra Kattimani², Rohit B Gadda ${ }^{3}$ ${ }^{1}$ Honorary Associate Professor in Physiology, MGM Medical College, Navi Mumbai, Maharashtra, INDIA. ${ }^{2}$ Associate Professor in Physiology, MGM Medical College, Navi Mumbai, Maharashtra, INDIA. \\ ${ }^{3}$ Department of Oral Medicine and Radiology, MGM Dental College and Hospital Navi Mumbai, Maharashtra, INDIA.}

\section{*Correspondence}

\section{Dr. Mahantayya Veerabhadrayya}

\section{Math}

Department of Physiology, MGM

Medical College, Navi Mumbai-410209, Maharashtra, INDIA.

Phone: +919619819864

Email: mathmv@rediffmail.com

\section{History}

- Submission Date: 06-07-2020;

- Review completed: 24-08-2020;

- Accepted Date: 01-09-2020.

DOI : 10.5530/ijcep.2020.7.3.32

Article Available online

http://www.ijcep.org

\section{Copyright}

(C) 2020 Phcog.Net. This is an openaccess article distributed under the terms of the Creative Commons Attribution 4.0 International license.

\section{Dear Sir,}

We have read your nice editorial which shows that yoga can be of a great help to combat COVID problems and to prevent spread of COVID infection. [1] Yoga helps to improve respiratory health and immunity, both of which are involved in the prevention and healing from COVID-19. ${ }^{[1]}$ The guidelines for healthcare workers for prevention of COVID-19 show how infection can be prevented with use of mask, goggle, hand hygiene, etc. ${ }^{[2]}$

Yoon, et al. reported that use of chlorhexidine mouthwash for $30 \mathrm{sec}$ is effective in decreasing the viral load in the saliva in two patients with COVID-19 infection. ${ }^{[3]}$ This study clearly shows the effect of chlorhexidine on corona virus in saliva. Curry leaves (Murraya koenigii Spreng, a medicinal plant and green leafy vegetable used as spice in food preparation) can be safe, effective and economical for maintaining good oral health and curry leaves mouthwash is effective in maintaining the $\mathrm{pH}$ of saliva similar to chlorhexidine mouthwash. ${ }^{[4,5]}$ Curry leaves contain volatile essential oils (sesquiterpenes, monoterpenes and saponin), carotene, total folic acid, riboflavin, iron, calcium, phosphorus and zinc. [6-8] They have antibacterial, antiviral, antioxidant, anti-diabetic, anti-inflammatory, antitumor and neuroprotective activities. ${ }^{[9]}$ Curry leaves mouthwash is helpful in reducing dental plaque and gingivitis. ${ }^{[10]}$ Kapur $\mathrm{S}$ has formulated a mouthwash based on FSSAI-approved nutraceutical-contains plant ingredients that are rich in saponins (a compound that disrupts fat just like a soap or a detergent). ${ }^{[1]}$ Coronavirus- 2 which causes COVID-19, is known to attack human cells first with a spike protein that is located on the virus. This spike protein is embedded in an envelope of fat. As soap and detergents disrupt this fat layer, saponin present in the mouthwash formulated by Kapur $S$ also disrupts the fat layer of corona virus. Thus essential oils containing terpene and saponins may be of help in reducing COVID-19 infection. ${ }^{[1]}$ Essential oils are lipophilic by nature, hence their virucidal activity is probably due to disruption of the viral membrane. ${ }^{[12]}$ Mouthwashes reduce the viral load in the short term where the greatest potential for infection comes from, saliva, oral cavity and throat ${ }^{[13,14]}$ Mouthwashes cannot inhibit the production of viruses in the cells. Curry leaves mouthwash containing essential oils and saponin can help in reducing viral load in saliva and this can be helpful in reducing spread of COVID-19 infection.

\section{REFERENCES}

1. Pal GK. Yoga to combat and prevent COVID-19. Int J Clin Exp Physiol. 2020;7(2):46-7.

2. Guidelines for healthcare workers for prevention of COVID-19. Int J Clin Exp Physiol. 2020;7(2):88

3. Yoon JG, Yoon J, Song JY, Yoon SY, Lim CS, Seong $H$, et al. Clinical significance of a high SARS-CoV-2 viral load in the saliva. J Korean Med Sci. 2020;35(20):e195

4. Ramesh G, Nagarajappa R, Madhusudan AS, Sandesh N, Batra M, Sharma A, et al. Estimation of salivary and tongue coating $\mathrm{pH}$ on chewing household herbal leaves: A randomized controlled trial. Anc Sci Life. 2012;32(2):69-75

5. Gupta A, Purohit A. Effectiveness of curry-leaf mouthwash in maintaining salivary and tongue ph as compared to chlorhexidine mouthwash: A randomised controlled trial. J Nat Ayurvedic Med. 2018;2(1):000114.

6. Math MV, Balasubramaniam P. Curry leaves. Br Dent J. 2004;197:64

7. Math MV, Balasubramaniam P. Physical properties of cold extract of curry leaves (Murraya Koenigii Spreng). Ind J Physiol Pharmacol. 2005;49(4):491-2.

8. Rajendran MP, Pallaiyan BB, Selvaraj N. Chemical composition, antibacterial and antioxidant profile of essential oil from Murraya koenigii (L.) leaves. Avicenna J Phytomed. 2014;4(3):200-14.

9. Gahlawat DK, Jakhar S, Dahiya P. Murraya koenigii Spreng: An ethnobotanical, phytochemical and pharmacological review. J Pharmacogn Phytochem. 2014;3(3):109-9.

10. Varghese A, Babu HM, Kukkera PN. Comparative evaluation of efficacy of Murraya koenigii and chlorhexidine gluconate in the treatment of gingivitis: A randomized controlled clinical trial. J Ind Soc Periodontol. 2018;22(5):427-32.

11. Kapur S. BITS Pilani professor bets on mouthwash that stops coronavirus progression. 2020. [updated 2020 March $30^{\text {th }}$.

12. Nadjib BM. Effective antiviral activity of essential oils and their characteristic terpenes against coronaviruses: An update. J Pharmacol Clin Toxicol. 2020;8(1):1138.

13. MeisterTL, Brüggemann $Y$, Todt $D$, Conzelmann $C$, Muller JA, Grob R, et al. Virucidal efficacy of different oral rinses against SARS-CoV-2. J Infect Dis. 2020;222(8):1289-92.

14. Aggarwal KK. Gargling is a potential preventive strategy to reduce COVID-19 transmission. Emedixnesus. 2020.

Cite this article: Math MV, Kattimani YR, Gadda RB. Mouthwashes Help in Reducing Spread of COVID-19 Infection. Int J Clin Exp Physiol. 2020;7(3):127. 